\title{
Phenomenology in nursing research: reflection based on Heidegger's hermeneutics
}

\author{
La fenomenología en investigación de enfermería: reflexión en la hermenéutica de Heidegger \\ Fenomenologia na pesquisa em enfermagem: reflexão com base na hermenêutica de Heidegger
}

Raúl Fernando Guerrero-Castañeda ${ }^{1}$

Tânia Maria de Oliva Menezes²

Marta Lenise do Prado ${ }^{3}$

1. Universidad de Guanajuato, Campus CelayaSalvatierra, Departamento de Enfermería Clínica. Celaya, Gto. México

2. Universidade Federal da Bahia, Escola de Enfermagem. Salvador, BA. Brasi

3. Universidade Federal de Santa Catarina, Departamento de Enfermagem, Programa de Pós-graduação em Enfermagem.

Florianópolis, SC. Brasil.
Corresponding author:

Raúl Fernando Guerrero Castañeda.

E-mail: ferxtom@hotmail.com

Submitted on $02 / 21 / 2019$

Accepted on 06/13/2019.

DOI: 10.1590/2177-9465-EAN-2019-0059

\section{Abstract}

Objective: To reflect on the use of phenomenological analysis in nursing research through the hermeneutical circle of Martin Heidegger. Method: Theoretical reflection based on Martin Heidegger's concepts through literature review. Results: Phenomenology is a philosophical referential to address lived phenomena; Heidegger emphasizes the essence of being in the world bound in experiences, the hermeneutical circle is a methodological referential of analysis to understand the world lived by the being through a pre-understanding; an understanding and an interpretation to reveal the essence of the phenomenon Conclusions and implications for practice: Nursing can make use the hermeneutic circle to understand, from a philosophica view, the phenomena in the language of those who experience them, to unveil them and to understand the subjectivity of care.

Keywords: Philosophy, Hermeneutics, Qualitative Research, Nursing Research.

\section{Resumen}

Objetivo: Reflexionar acerca del uso del análisis fenomenológico en investigación de enfermería a través del círculo hermenéutico de Martín Heidegger. Método: Reflexión teórica basada en conceptos de Martín Heidegger a través de la revisión de literatura. Resultados: La fenomenología es un referencial filosófico para abordar fenómenos vividos; Heidegger enfatiza la esencia de ser en el mundo envuelto en experiencias, el círculo herméutico es un referencial metodológico de análisis para comprender el mundo vivido por el ser a través de una pre-comprensión; una comprensión y una interpretación para desvelar la esencia del fenómeno. Conclusión e implicaciones para la práctica: La enfermería puede hacer uso del círculo hermenéutico para comprender, a partir de una visión filosófica, los fenómenos en el lenguaje de quienes los experimentan, para desvelarlos y comprender la subjetividad del cuidado.

Palabras clave: Filosofía, Hermenéutica, Investigación Cualitativa, Investigación en Enfermería.

\section{Resumo}

Objetivo: Refletir sobre o uso da análise fenomenológica na pesquisa em enfermagem por meio do círculo hermenêutico de Martin Heidegger. Método: Reflexão teórica baseada nos conceitos de Martin Heidegger através da revisão de literatura. Resultados: A fenomenologia é um referencial filosófico para abordar os fenômenos vividos. Heidegger enfatiza a essência de estar no mundo envolto em experiências, o círculo hermenêutico é um referencial metodológico de análise para compreender o mundo vivido pelo ser através de uma pré-compreensão, uma compreensão e uma interpretação para desvendar a essência do fenômeno. Conclusão e implicações para a prática: A enfermagem pode fazer uso do círculo hermenêutico para compreender, a partir de uma visão filosófica, os fenômenos na linguagem de quem os vivencia, para revelá-los e compreender a subjetividade do cuidado.

Palavras-chave: Filosofia, Hermenêutica, Pesquisa Qualitativa, Pesquisa em Enfermagem 


\section{INTRODUCTION}

The human being is immersed in the world, every lived moment or experience in which he/she is immersed does not separate from him/her, but on the contrary, it makes him/her recreate and travel through the world which becomes intentional in order to change with him/her.

All experience is prone to be studied, understood, interpreted; to be able to interpret it is necessary to know the experience itself from the perspective of the human being, however, this experience is not a mere description, it implies that the human being has already carried out a process of introspection to understand him/herself within that experience, such a situation allows him/her to understand the world that is part of him/her.

The lived experience is what happens in the human being in his/her daily life, everything that happens is a phenomenon; hence, it can be approached with a phenomenological vision.

Phenomenology began by evoking the "going to things themselves" 1 , giving way to phenomenology allows to reveal the phenomena in the description of them as they appear in the human being, however, phenomenology takes a turn in the sense that not only the description is such, this description would remain in a simple experience as empiricism can affirm; this experience implies that the human being is inside a world, within a context, to be able to meet him/her, he/she must already have an understanding of him/herself, an interpretation; this is not a single description of the human being in the lived experience, but rather it has already led to a process of a dependent individual analysis of his/her relationship with the world, that relationship is intimate and unitary. ${ }^{2,3}$

Heidegger's phenomenology shows a relationship of the human being with his/her world, hereafter he/she described the term Dasein, that means there-being, it is, a human being in the world approached by him/herself in every experience of his/her life, which can be brought to consciousness by him/herself and that can express through language..$^{4,5}$

This phenomenology is considered existentialist, because it has the essential reason of the human being which is manifested in his/her daily existence, that reason of being involves the ontology itself, the essence of each being. Heidegger's concern is linked to being in his/her attempt to discover him/herself as a being and the path that he/she takes to reach this understanding of him/herself.

The Heideggerian vision has been adopted in nursing, both in a philosophical way, because of its interest in the essence of the human being, and as a method to conduct investigations with a phenomenological essence, since the reason for Heidegger's phenomenological investigation is to be able to understand to the extent of the experiences of the human being ${ }^{6}$, who is the subject of the nurse's care.

The nursing whose ontological foundation is the care of the human being must learn from methods that also allow to visualize it as a philosophy to achieve access to the human being, where the "people who receive care" and the "people who provide care" are involved, these people far from their conceptual titles are human beings, both involved in experiences that become significant, allowing the interpretation of care in order to help other nurses to understand it. ${ }^{7}$

In the present article we try to make a theoretical reflection of Martin Heidegger's phenomenology as a philosophy and highlight the concepts related to the method for the understanding of the phenomena that concern the great phenomenon of care, considering that every phenomenon experienced by human beings constitutes a reason to be of care and care is the very own ontology of nursing, so the question to reflect on is: What is the way to understand phenomena from a hermeneutical phenomenological vision in a nursing research?

The objective of this article is to reflect on nursing research through the hermeneutics of Martin Heidegger.

\section{METHOD}

It is a theoretical reflection based on the concepts of Martin Heidegger, made with basis on the concepts of hermeneutical circle, pre-understanding, understanding and interpretation, recovered from the literature of Martin Heidegger as referential.

\section{THEORETICAL REFLECTION}

\section{Approach to the phenomenology of Martin Heidegger}

Phenomenology can be considered a method that allows deepening the reflection of the phenomena that occur in the world, unifying the subject-object relation, involving the human being of his/hers experiences facing the world, as Heidegger says: "leave and make see by yourself that which is shown, as it is shown from yourself". 4:45

In phenomenological research, the nurse must consider the "phenomenon" as something experienced, so that it occurs in some way, is what appears in the world and is conceived of meaning by the human being, "what is shown, the being of entities, his/her meaning, his/her modifications and derivatives". 4:46 No other interpretation can be given to the expression, but the same phenomenon is that which manifests, which is shown, which occurs in all that comes to meets us as we live, the being understands and interprets it. ${ }^{4}$

The phenomenology of Martin Heidegger is considered a hermeneutical existentialist phenomenology whose objective is the understanding of the phenomena that are brought to the consciousness of the human being.

The interest for Heidegger is the being, central object of phenomenology "to be in any case is the being of an entity". 4:18 Entity is everything we talk about this or that. It is also what we are. It is everything that is presented immediately, a way of acting The phenomenology seeks the understanding of being, through his/her existence with entities simply given. Each entity appears in the movement of veiling and revealing its ways of being. What is veiled, what is not shown, the researcher seeks to disclose or 
reveal. This is the movement of phenomenology: trying to disclose what is hidden or covert.

When the nurse researcher starts the disclosure of the phenomenon, he/she makes a suspension of his/hers preconceptions and theories, he/she does not deny or affirm it, what he/she does is to put in parentheses the reality and the phenomenon to be investigated and thus, questions the world experienced by the entity who is interrogated.

From this perspective, phenomenology seeks the understanding and the interpretation of each particular case of the experience, in the way in which life has manifested itself in the being and in the way in which this life speaks of itself.

Heidegger goes beyond the description of this phenomenon of the experience, but refers to it as an understanding and interpretation, an explanatory clarification of the sense of being, where the dimension of consciousness is expressed in language and is historical-socio-cultural. The human being is a being, therefore, in the world, both physical (that demeans the conception of being in the world from the biological point of view), but also the relationships with others are locked up, in such a way that this world, the being builds and modifies it immersed in it. ${ }^{4}$

Heideggerian phenomenology is a philosophy and at the same time it is constituted as a method that guides the reflection of the investigation to understand the phenomena, the method of analysis starts from the personal understanding of the same person as their own revelation, it is an understanding and an interpretation, therefore it is hermeneutic. ${ }^{2}$

\section{The phenomenon of care in nursing research with a Heideggerian perspective}

The care within the transforming paradigm of nursing is visualized as a complex phenomenon from the point of view that considers the person or being as a complex being.

To speak of care in Martin Heidegger's concepts is to speak of occupation and concern; he considers the care as fundamental constitution of the human, being able to manifest in an innate and medium way by the daily occupation, in which nothing is determined, situation in which the presence occurs, which is taken by the world of he deals with.

On the other hand, care can be manifested as an authentic concern, characterized by the condition in which the occupation respects and considers the originality of who assumes "to take care of food and clothing, to treat the sick body, it is also a concern". 4:137

Heidegger reflects on the sense of care or healing, as the self-expression of being-there, a reason for his essence, a proper understanding of the being as caring for him/herself and at the same time taking care of the other, taking care of the world, taking care of everything. Care as a cure in Heidegger's words in the sense of manifestation, that manifestation comes from the interaction being-in-the-world as concern, as being aware of the other, taking care of myself, doing for me, doing for the other, doing with the other, care is the basis of the existence of being, the existence comes from his/her understanding and understanding is the ontological reason of being him/herself ${ }^{4}$

Nursing is the science whose purpose is the care, in a way that Heidegger's perspective on care as a cure favors that phenomena can be considered within this reason to be. Nursing philosophically manifests itself as care and preservation of life and health. The nurse researcher can come to understand, because through reflection and hermeneutic analysis can reach that goal and be able to express, interpret in language the existence of the phenomena of care. Because of the descriptive description of descriptive phenomenology, through the hermeneutic circle one can come to understand, starting from the individual preunderstanding and from that expressed by the being, it is only the being who has experienced the phenomenon, who has experienced about him/herself this existence. ${ }^{1,8,9}$

It should be noted that the existentialist phenomenology contemplates every lived moment or experience lived in a way where the being is one with the world, he/she does not consider the world apart, Heidegger emphasizes it by saying the Dasein or Being-there, is because the being is one with the world, therefore when the research addresses care, it can address it from who receives the care and who provides it; it is limiting to say that the nurse cannot be approached, because then he/she would stop being a human being.

The care from a phenomenological vision contemplates being-there in different situations or phenomena that are part of the care, the experience of a disease, the experience of health, the experience of being a mother; complex phenomena such as death, the existential encounter between the one who gives care and the one who is in pursuit of meeting the extra corporeal. ${ }^{10}$

When the care is approached in the research with the view of Heidegger's phenomenology, then it must be channeled under a non-deterministic, hegemonic approach; that is precisely what phenomenological research apprehends of the phenomena to be studied ${ }^{11}$, focuses the care with a comprehensive view, the understanding of being highlights the understanding of the phenomenon of caring wrapped into substance by a context that gives meaning to personal perception.

The nurse interacts as being-there with the people he/she cares for and investigates, care is manifested as time based on a person's understanding. Thought then enters into the reflection that allows him/her to visualize him/herself in the world and the manifestation of human responses is what Heidegger calls Existence,${ }^{4}$ not only the fact of being present in the phenomenon, because then it is not lived or experienced, to feel lived immersed in the phenomenon, it is then when the being manifests him/ herself, exists.

In the same way, care as a phenomenon of study in the investigation of the being is so complex, involves a series of mechanisms in which the understanding of the same in its multiple manifestations is sough; manifestations of the same phenomenon, because it is not the researcher who is going to bring the phenomenon, but a meeting with him/her will take place, the phenomenon is revealed, hence it is said that despite the fact 
that the phenomenon already exists, this one is manifesting to the investigator opening the way to him/her to be able to obtain of him/herself all information that allows him/her to understand and to transmit it.

Each situation of care or good, situation related to him/her will have various dyes that will be glimpsed not only as a brief description, the hermeneutics suggests the understanding of the lived phenomena, same understanding that must be interpreted to understand the world where the being is immersed.

It is believed that the care being so complex cannot be understood and, therefore, the phenomenology should lack scientific rigor, however, these same diverse dyes of seeking the encounter with the phenomena are part of the phenomenology as a method, resulting in difficult but not impossible and much less spontaneous, is an arduous, rigorous, reflective, analytical and above all, stripped of personal researcher's concepts. ${ }^{4}$

In a certain way, the phenomena subject of research by nursing can be approached phenomenologically insofar as the researcher is able to be understanding, sensitive, open and above all understand in him/herself that the phenomenological path is a way of being part of the phenomenon that the being lives or experiences. ${ }^{7,12}$

Within the transformative paradigm of nursing as researcher and that can make of him/herself and for him/herself phenomenology as a method to reach this level of research, we discover that we cannot come close to consider the explanation or prediction of phenomena that have not been understood by the researchers, so that the truth comes from the being that has already apprehended in him/herself to be part of it and that research should not question its veracity, but instead try to unify to transmit it and thus lead an understanding of nursing care through methods that can and are able to lead the researcher to that objective.

This vision of the investigation leads to approach the concepts of Martin Heidegger as a philosophical referential, which can guide the researcher to channel the phenomenon, the next point will be to unveil the structural path that allows understanding the phenomena in the reason of analysis as a methodological referential to be able to achieve it.

\section{Phenomenology as a method of hermeneutical phenomenological analysis: proposal of the hermeneutical circle}

Taking into account the process of construction of phenomenological projects in nursing, the path is considered in order to be able to construct the results. The philosophical referential base of the existentialist phenomenology of Martin Heidegger must be present throughout the methodological path of the research project, in this section reference is made to the structural part of the construction of results.

The constructions of the interpretations in phenomenological investigations with the Heideggerian referential suppose an arduous work, because they mark the guideline to be able to understand, a very vast term and at the same time "little understood" that is considered unattainable, it is not only through the language of a person, as one discovers the phenomena that one wants to understand, this discovery is not made by the researcher at his/her convenience, but by starting from a way of carrying out this method.

Since phenomenology is a method, a path can be considered, it is a series of moments in the structure of understanding the phenomenon ${ }^{13}$, they do not represent static steps, but dynamic moments and from where the units that make up a structure are part from, and in turn, from the structure to the unit itself, hence they are units of meaning. ${ }^{14,15}$

It is from the discourse of the person, from where it begins to be able to understand a phenomenon that little by little will show itself. $4,13,16,17$ Things have a meaning; what is understood is not the meaning, they are the beings or the being. ${ }^{2}$ In this way, the in-depth phenomenological interview is imperative for the production of the person's discourse.

The phenomenological interview is understood as a social encounter where there is a conjunction of mutual perceptions through empathy and intersubjectivity ${ }^{18-21}$, so that this type of interview seeks the understanding of the phenomenon and not the explanation of it. This understanding helps the researcher to build knowledge about the perceptions of the interviewed subject regarding the human being located in the world.

The phenomenological encounter that occurs in the interview is given in the existence of the same between interviewed subject and interviewer researcher, this encounter is unpredictable and without established or structured rules s,22,23. $^{19}$. The interview scrutinizes in a sense what the human being has lived or experienced, this meaning is understood by phenomenology and is the result of the interaction between discourse and understanding, which are the fundamental parts of the phenomenological interview; thus allowing human history to continue in the action of the same being and in his/her perception-conception of the world.

Heidegger expresses: "what you ask in the question that you are trying to develop is the being [...] that what you ask, the sense of being, a peculiar repertoire of concepts [...] that what you ask in the question which is interrogated by the entities themselves" . 4:15-16

The result of the phenomenological interview is to return to the phenomenon itself ${ }^{22}$, if properly used it is a reflection of the being in the understanding of the phenomenon in question in the world as it manifests and is apprehended by the subject interviewed.

The strategy of phenomenological analysis is to identify, through the approach, the essence of a phenomenon and transform the experience lived in a textual expression of its essence. This essence is specified within the theoretical foundation of the qualitative method in its phenomenological approach.

From the phenomenology of Heidegger, a hermeneutical circle is proposed to understand the phenomenon. The hermeneutic circle supposes the understanding of the being, 
it is not an understanding that ends in an interpretation, but it continues in the perspective of the reason of the same being. $4,16,17,24$

When interpreting a text, the interpreter should make the text speak like another person in dialogue with him/herself ${ }^{2}$. Interpretation is an understanding without presuppositions of something given previously.

The hermeneutic circle indicates the way in which an attempt is made to describe a mode of interpretation of the data, this understanding of the phenomenon is not neutral, since it starts from a previous structure: the same participant subject in its description ${ }^{25}$, since "doing in an express way and seeing through it the question that interrogates for the sense of being, asks for the previous and adequate analysis of an entity (the being-there), focusing on his/her being". $4: 17$

When the descriptive text is read, the projection is denoted in relation to the sense of a whole ${ }^{26}$. It is based on the previous conception which will determine comprehension and interpretation ${ }^{17}$.

Analysis based on a hermeneutic circle is generated by previous conceptions that have already been understood, in order to move on to a new understanding because of the consciousness that has been shown.

The circle includes three moments that will be explicit below, Heidegger reflects that one cannot start from the things themselves, but from what those things contain, an essence already in them, a way of understanding. When one understands something, he/she has an interpretation and the circle continues. Therefore, it can be made explicit that:

The "circle" in understanding is inherent in the structure of meaning, a phenomenon that has its roots in the existential structure of being-there, in interpretive understanding. The entity to which in terms of being in the world is its own being, has a circular ontological structure. $4: 172$

The first moment of the circle is the pre-understanding, it is the moment of visualization of the Dasein or Being-there, the person in general, how that person or entity visualizes him/ herself by virtue of the articulation of the discourse. It is the guide of the study of the phenomenon, where the researcher begins to construct the sense of being in the same, the entity that is in front of him/her; for Heidegger says that it is the constitution of being-there in him/herself.

It is the setting in motion of the vision of the retrospective of being him/herself in the discourse and how it is articulated based on his/her historicity in temporality. The author points out that it is the first moment in the hermeneutic circle because he already considers an interpretation in the way in which the position of the being is articulated and makes possible the next articulations. ${ }^{4,8,9,16}$

It includes, on the one hand, the discourse articulated by the participants, a type of prior conception of the being with respect to the phenomenon, because as mentioned, it is something that the author already internalized and understood and that is why he considers certain phenomena from his own perspective, which will be barely shown through language.

On the part of the researcher, is assumes the preconceptions that will guide the way for understanding in the literature review, these preconceptions arise from what other "entities" that were also questioned by the phenomenon in being and that expose their understanding of the phenomenon. Heidegger mentions that:

"The previous guiding conception that supports everything now serves for a main discussion and elucidation. If the judgment that is made of that previous conception is what it pretends to be, then it means the realization of the question of itself $[$...] everything in life is something which we cannot say anything directly about. Still somehow it must be understood". ${ }^{16: 32}$

Heidegger says that what is said about something is already an understanding, but that it still contains a new way of understanding it from the point of view of the interpreter. Be part of the discourses and articulated with what is spoken of the phenomenon to achieve this pre-understanding. It is the ontic moment that supposes an "understanding of the middle term and the being can be, furthermore, transited from traditional opinions and theories about the being, and in such a way that these theories remain hidden in their condition of sources of the dominant understanding"-15

The second moment in the hermeneutic circle is the understanding itself, which frames the notion of seeing the articulations indicated in the first moment. The phase of understanding marks an open door to the totality of being-inthe-world (being-there), because "a certain understanding of the being is in each case already included in all apprehension of an entity [...] The being is, according to the term of the medieval ontology, a transcendens (transcendental)". $4: 12$

Then, everything that has been apprehended from the phenomenon through the discourse of being questioned now comes to a new form of articulation on the part of the interpreter and that has to be understood by in reason of a path constituted by the philosophical referential that will allow to reveal the phenomenon, since "the understanding of the being is properly a determination to be of being-there" ${ }^{4: 22}$ That determination comes from the transmission of what is being through the researcher and which was manifested through language and that means for him/her to enter the phenomenon and project a horizon of the subject's own history. $3,4,27$

Heidegger mentions "the appropriation of the understood, but still veiled, always unveils it under the guidance of a directing view that points out that in respect to which the understood must be interpreted". $4: 168$

This moment of understanding emphasizes the connection that the ontic moment has, that is, all the units of meaning and 
how they interrelate to give an explanation (interpretation) of the phenomenon.

The understanding is a hermeneutic, to interpret requires understanding. That understanding comes in that relationship between the moments expressed by the participant, it means knowing something of the being, the being is complex, and it is a whole, to understand it is to bring something out of it to be able to know about that something. That knowledge about that something is understanding, it is the convergence of the units of meaning.

The moment of interpretation is the last and the beginning. This moment moves based on the priority construction. The interpretation indicates a contribution of understanding and opens to the new pre-understanding. Because the human being is in a whole circle and the phenomena that he/she faces are nothing but a constant turn in his/her own being.

The interpretation is therefore a result of being and whose interpretive moment is science, is the articulation of the phenomenon unveiled. The moment of interpretation constitutes a fundamental methodological part because it is inherent to the experience of the human being and in the researcher it constitutes a task of creation also from the understanding and is given in the handling of the language and is where the words and the meanings have relevance. ${ }^{4}$

The phenomenon is manifested in the being and it interprets and gives meaning to it, while the researcher is the reflector of this phenomenon because it concerns to him/her starting from that pre-understanding of the subject, understanding the phenomenon and interpreting it, giving it meaning, dismembering it again to be able to create it, those parts united in understanding are visualized and, for this reason, the phenomenon revealed is shown. Heidegger affirms that "the interpretation is based in all cases on a previous view that cuts out what has been taken in the prior having in agreement with a certain possibility of interpretation" ${ }^{4: 168}$, that is to say, the interpretation has something previously understood and it becomes manifested in the way in which this previous understanding was discussed and conducted.

The possibility of vision of knowledge cannot be possible except when that "final" interpretation is configured in the previous situation or pre-understanding of the phenomenon in the subject. The same understanding is already an essential part because it corresponds to the potentality-for-being of Being-There.

The way to enter the circle determines the fundamental basis of the understanding of a lived phenomenon, without a doubt, it is not like a circle of the researcher, but a reason of knowledge based on the structure of the subject's own existence, manifesting its to be in the world in relation to the phenomenon and how it transcends it, since "any interpretation that entails understanding must already have understood what is to be interpreted in it". 4:170

The interpretation is the philosophical language that helps to see the phenomenon in the horizon of knowledge, in this sense the concern with the knowledge of the truth, starting from the original vision of a being, a person immersed in the care will determine the notion of search and by itself responds to the scientific validity that research always seeks, since the essence itself is explicitly true ${ }^{28}$, so that care acquires a characteristic that must transform the ways of knowing the phenomena immersed in itself.

The hermeneutic circle allows the understanding of a phenomenon and its articulation in a language that stimulates the phenomenon's own experience (Figure 1).

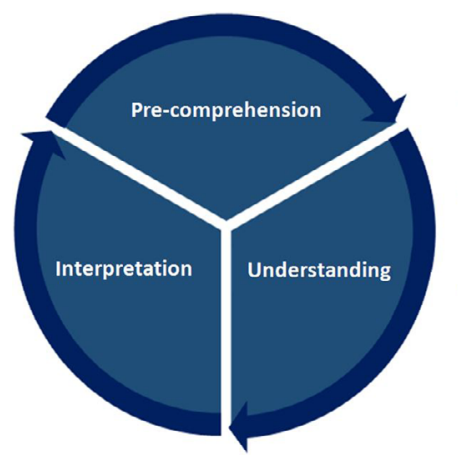

- Pre-comprehension: Median understanding. Literature review and phenomenological interview

- Understanding: Convergence of meaning units, unveiling of the interrogated phenomenon

- Interpretation: Articulation of the understood phenomenon

Figure 1. Representation of the hermeneutical circle. Source: Authors' own elaboration, 2019

\section{CONCLUSIONS AND IMPLICATIONS FOR THE PRACTICE}

Martin Heidegger's phenomenology focuses on his interest in the understanding of the human being, a being-there thrown into the world who lives experiencing different phenomena, some of which are related to care, because being is the care itself. The understanding comes from the human being him/herself because of his/her existence in the world, in his/her daily occupation the phenomena that are going to be revealed to the researcher are submerged and which requires the phenomenological method to be able to interpret them.

A hermeneutical circle with structural components is proposed to achieve understanding from a pre-understanding that is vague and median; understanding and interpreting require research and philosophical skills in the Heideggerian referential in order to access them and in this way reveal an essential part of the process of caring with a perspective that starts from the very being immersed in the world of care.

This philosophical approach to Heidegger's vision also constitutes a research method and has been used to direct research in the areas of health, especially in nursing, because care is a complex phenomenon that involves intersubjectivity, which allows us to understand various phenomena experienced by cared human beings.

The understanding of care as a subjective situation with multiple perceptions is the reason why phenomenology allows an approach to these phenomena and provides knowledge to discipline a broader view on the various situations of care.

Phenomenology also requires to be strengthened as a research method and requires having a congruence in the 
formulation of projects in the discipline, which will allow its continuous approach and development with well-founded elements, but maintaining that essence of going to the same things and to the understanding of the being that is involved in the process of caring.

\section{REFERENCES}

1. Husserl E. La idea de la fenomenología. Barcelona: Herder; 2012.

2. Schmidt LK. Hermenêutica. Petrópolis: Vozes; 2014.

3. Blanco JEP. The Ontology is Possible Only as Phenomenology. Around the Phenomenology of Martin Heidegger. Franciscanum [Internet] 2015 Jan/Jun; [cited 2018 Nov 1]; 57(163):87-123. Available from: http://www.scielo.org.co/scielo.php?script=sci_arttext\&pid=S0120$-14682015000100004 \&$ Ing=en\&nrm=iso\&tlng=es

4. Heidegger M. El ser y el tiempo. México: Fondo de Cultura Económica; 2015.

5. Heidegger M. Sobre a essência da linguagem. Petrópolis:Vozes; 2015.

6. Ramírez-Pérez $M$, Cárdenas-Jiménez $M$, Rodríguez-Jiménez $S$. El Dasein de los cuidados desde la fenomenología hermenéutica de Martín Heidegger. Enferm Univ [Internet]. 2015; [cited 2018 Nov 1]; 12(3):144-51. Available from: http://www.scielo.org.mx/scielo. php?script=sci_abstract\&pid=S1665-70632015000300144\&lng=es\& nrm=iso

7. Waldow VR. Enfermagem: a prática do cuidado sob o ponto de vista filosófico. Invest Enferm Imagen Desarro [Internet]. 2014; [cited 2018 Nov 5]; 17(1):13-25. Available from: https://www.redalyc.org/ pdf/1452/145233516002.pdf. DOI: http://dx.doi.org/10.11144/ Javeriana.IE17-1.epdc

8. Missaggia J. Heidegger e a transformação da fenomenologia: a aproximação da hermenêutica e o afastamento de Husserl. Ágora Filosófica [Internet]. 2015 Jan/Jun; [cited 2018 Nov 5]; 1(1):135-48. Available from: http://www.unicap.br/ojs/index.php/agora/article/ view/619/488

9. Silva AR. Heidegger e a questão do sujeito: indícios para um filosofar sem imagens. Problemata [Internet]. 2013; [cited 2018 Nov 5]; 4(2):278309. Available from: http://periodicos.ufpb.br/ojs/index.php/problemata/ article/view/15454/9844. DOI: http://dx.doi.org/10.7443/problemata. v4i2.15454

10. De Almeida CSL, Sales CA, Marcon SS. The existence of nursing in caring for terminally ills'life: A phenomenological study. Rev Esc Enferm USP [Internet]. 2014 Feb; [cited 2018 Nov 5]; 48(1):34-40. Available from: http://www.scielo.br/scielo.php?script=sci_arttext\&pid =S0080-62342014000100034. DOI: http://dx.doi.org/10.1590/S0080623420140000100004

11. Rodríguez-Jiménez $S$, Cárdenas-Jiménez $M$, Pacheco-Arce AL, Ramírez-Pérez M. Una mirada fenomenológica del cuidado de enfermería. Enferm Univ [Internet]. 2014 Oct; [cited 2018 Nov 10]; 11(4):145-53. Available from: http://www.scielo.org.mx/scielo. php?script=sci_arttext\&pid=S1665-70632014000400005

12. Waldow VR. Cuidar de sí, cuidar del otro, cuidar del todo: implicaciones para la salud y enfermería. Enferm Cuid Humanizado [Internet]. 2016; [cited 2018 Nov 10]; 2(1):53-6. Available from: http://revistas.ucu.edu. uy/index.php/enfermeriacuidadoshumanizados/article/view/783

13. Mantzavinos C. O círculo hermenêutico: que problema é este? Tempo Soc [Internet]. 2014; [cited 2018 Nov 10]; 26(2):57-69. Available from: http://www.scielo.br/pdf/ts/v26n2/v26n2a04.pdf

14. Martínez Miguélez $M$. Hermenéutica y análisis del discurso como método de investigación social. Paradigma [Internet] 2015; [cited 2018
Nov 1];23(1):9-30. Available from: http://revistas.upel.edu.ve/index.php/ paradigma/article/view/3049/1442

15. Sousa RS, Galiazzi MC, Schmidt EB. Interpretações fenomenológicas e hermenêuticas a partir da análise textual discursiva: a compreensão em pesquisas na educação em ciências. Rev Pesq Qual [Internet]. 2016 Dec; [cited 2018 Nov 10]; 4(6):311-33. Available from: https://editora. sepq.org.br/index.php/rpq/article/view/39

16. Heidegger M. Marcas do caminho. Petrópolis: Vozes; 2008.

17. Kempfer SS, Prado ML, Sebold LF, Girondi JBR. Heidegger's hermeneutics as a data source in a phenomenologic study. Inv Qual Saúde [Internet]. 2015; [cited 2018 Nov 10]; 1:108-12. Available from: http://proceedings.ciaiq.org/index.php/ciaiq2015/article/viewFile/25/24

18. Gil AC, Yamauchi NI. Elaboração do projeto na pesquisa fenomenológica em enfermagem. Rev Baiana Enferm [Internet]. 2014 Sep/Dec; [cited 2018 Nov 10]; 26(3):565-73. Available from: https://portalseer.ufba.br/ index.php/enfermagem/article/view/6613/6693

19. Moreno López S. La entrevista fenomenológica: una propuesta para la investigación en psicología y psicoterapia. Rev Abordagem Gestal [Internet]. 2014 Jun; [cited 2018 Nov 10]; 20(1):63-70. Available from: http://pepsic.bvsalud.org/scielo.php?script=sci_arttext\&pid $=$ S1809-68672014000100009

20. Carvalho A. Metodologia da entrevista: uma abordagem fenomenológica. Rio de Janeiro: Agir; 1991.

21. Guerrero-Castañeda RFMenezes TMO, Ojeda-Vargas M. Characteristics of the phenomenological interview in nursing research. Rev Gaúcha Enferm [Internet]. 2017 Jul; [cited 2018 Nov 10]; 38(2):e67458. Available from: http://www.scielo.br/scielo.php?script=sci_arttext\&pid =S1983-14472017000200701. DOI: http://dx.doi.org/10.1590/19831447.2017.02.67458

22. Paula CC, Padoin SMM, Terra MG, Souza IEO, Cabral IE. Modos de condução da entrevista em pesquisa fenomenológica: relato de experiência. Rev Bras Enferm [Internet]. 2014 May/Jun; [cited 2018 Nov 10]; 67(3):468-72. Available from: http://www.scielo.br/scielo. php?script=sci arttext\&pid=S0034-71672014000300468\&Ing=en\&nr m=iso\&tlng=pt. DOI: http://dx.doi.org/10.5935/0034-7167.20140063

23. Rocha Moreira RC, Mendonça Lopes RL, Andrade Santos N Entrevista fenomenológica: peculiaridades para la producción científica en enfermería. Index Enferm [Internet]. 2013; [cited 2018 Oct 1]; 22(1/2):107-10. Available from: http://scielo.isciii.es/scielo. php?pid=S1132-12962013000100024\&script=sci_abstract\&tlng=pt

24. Sebold LF, Kempfer SS, Girondi JBR, Prado ML. Perception of nursing faculty on the care: Heidegger constructions. Rev Esc Enferm USP [Internet]. 2016 Jun; [cited 2018 Oct 1]; 50(no.spe):39-46. Available from: http://www.scielo.br/scielo.php?script=sci_arttext\&pid =S0080-62342016001100039. DOI: http://dx.doi.org/10.4321/S113212962013000100024

25. Grondin J. The Hermeneutical Circle. In: Keane N, Lawn C, eds. The Blackwell Companion to Hermeneutics. Hoboken: John Wiley \& Sons 2016.

26. RapleyT. Los análisis de la conversación, del discurso y de documentos en Investigación Cualitativa. Madrid: Morata; 2014.

27. Sassenfeld AJ. Contribuciones de la filosofía fenomenológica y hermenéutica a una concepción intersubjetiva del vínculo analítico. Clín Inv Relac [Internet]. 2017; [cited 2019 Jan 2]; 22(3):554-80. Available from: https://www.psicoterapiarelacional.es/Portals/0/ eJournalCelR/V11N3 2017/07 Sassenfeld Contribuciones-filosofiafenomenologica-hermeneutica_CelR_V11N3.pdf. DOI: http://dx.doi. org/10.21110/19882939.2017.110307

28. Heidegger M. Introducción a la investigación fenomenológica. Madrid: Síntesis; 2006 